\title{
Reflections on the Economic Transformation and Upgrading, the Post-Modeling Specialty Construction in Higher Vocational Education
}

\author{
ZHANG, Ze \\ Jiangsu Vocational Institute of Commerce \\ Nanjing Jiangsu 210007 \\ zhangze65@163.com
}

\begin{abstract}
With the acceptance of the last key specialties in national model vocational colleges, higher vocational colleges enter a connotative construction period from expansion construction in an all-round way. The specialty construction of post-demonstration period should proactively adapt to the global industrial structure adjustment and the emergence of new industries, orient the demand of inbound enterprises to that of outbound enterprises, promote actively China's transformation and upgrade of economic, technology and equipment through professional transformation, and turn the specialty into industry, making it an effective weapon in raising China's industrialization standard and changing China's low end position in international industrial chain.
\end{abstract}

Keywords-economic transformation; industrial structure adjustment; division of labor in industrial chain; smiling curve; specialty transformation

\section{INTRODUCTION}

Since the reformation and open-door policy 30 years ago, vocational education has delivered more than 100 million qualified labors and professional skilled talents, providing important human resources for speeding up China's industrialization and a great contribution to the fastening of the development of advanced manufacturing, modern services and agriculture, and becoming a propeller to the concentrative development of middle-to-small-sized business industry.

Together with the economic globalization and the entry into the Third Industrial Revolution of the whole world, China speeds up its transformation and upgrading while Chinese enterprises also fasten their globalization processes. There have been world-shaking changes in China's industrial structures, and the existing specialty setup based on industrial structures is over simplified and narrowed in its services, which is no longer suitable to the demands for talent fostering required after the changed industrial structures and regional economic development as well as to the requirements of coalescing jobs and new industries[1]. Higher vocational institutes in China have experienced successively five important periods full of opportunities for development: merging and upgrading of schools, scale expansion, school-running assessment, construction of modeling institutes and construction of backbone institutes, which resulted in a qualitative leap in terms of school-running competence, branding positions and social impacts. After the acceptance check of the last batch of national modeling/backbone key specialties at higher vocational schools in 2015, higher vocational institutes has stepped into the period of content construction as against the expansion-typed construction in the past. Facing the adjustment of industrial structures and emerging industries, how should the post-modeling specialty construction is transformed?

\section{THE RELATION BETWEEN VOCATIONAL EDUCATION AND INDUSTRIAL REVOLUTION}

In industrialized societies, because of the demands for technical workers for big machine production, not only was compulsory education popularized, but secondary education was also developed. In industrialized societies, the productionorientation of education became prominent, and education was demanded by the society to deliver experienced labors for factories. Thus vocational education came into existence that became an important part of modern education. Along with the progresses in science and technology, demands for talents with strong skills by the adjustment in economic structures and the arrival of the era of popularized education are gradually raising the requirements for the levels of education-receivers.

Marx said: "The nature of big industries determines the transformation of labor, the changes of professions and the overall mobility of workers." When manufacturing enterprises were mainly engaged in primary commodities, junior technical workers were the main workforce of enterprises who were fit to the production demands with little technical content[2]. However, after the industrial structures were adjusted and products of enterprises upgraded, enterprises not only needed operation managers at higher levels, but also more technical workers at higher levels. And the foci of vocational technical education gradually moved upward from elementary, to secondary, to higher, and to application-oriented university levels.

And then look back the Third Industrial Revolution and the transformation and upgrading of world's economic development, followed by a revolution in vocational technical education. Many countries in the world regard vocational education and strengthening national power through skills as a strategic choice. In the new historical period, it is an arduous historical task for China's modern vocational technical 
education to foster experienced workers and middle-to-high level technicians with wide specialties[1].

\section{Challenges Facing the Post-Modeling Specialty CONSTRUCTION IN THE PERIOD OF ECONOMIC TRANSFORMATION AND UPGRADING}

\section{A. Higher vocational education bears the historical task of promoting the economic transformation and technological and facilities upgrading}

Firstly, though having become the world's second largest economic entity, China is still weak in its industrialized infrastructures. From the viewpoint of international division of labor in products and technologies, the largest part of China's products are low value added, and enterprises commonly lack core technologies and products with heavy dependence on foreign technological innovation. China's industries have not stepped out of the bottom of the smile curve yet[3].

Secondly, in the third run of international industrial transfer, many multi-national corporations did move some of their purchasing and $\mathrm{R} \& \mathrm{D}$ centers to China and China is leading in a few technological fields worldwide, but it is still a fact that China is a country at the level of simulating and importing technologies and a great number of enterprises are only traditional ones in semblance of high tech enterprises.

Thirdly, China's advantageous traditional industries are not capable to undertake transformation with high technologies, either to be adjusted and upgraded or obsolete. In the new run of competition in the fields of environmental protection, energy reservation, green movements, new energies and materials, the gap between China and the outside world has not been shortened.

Various challenges tell us that China is still weak in vocational technical education, unable to deliver a great number of technical talents who have hands-on skills and are good at technical breakthroughs and technological innovation. Higher vocational education bears the historical task of pushing forward China's economic, technical and facility transformation and upgrading[4].

\section{B. The challenge for China to rise peacefully and step out of} the middle-to-low position in the division of labor in the world's chain of industries

China is only second to the United States in GDP, but there are serious drawbacks in the structure and quality of its GDP. In the overall division of labor in the world's chain of industries, China is at a middle-to-low position, as is the embarrassment reflected in the chain of industries constructed by Apple in China. At present, competitive products in China's manufacturing industry are basically concentrated in the low value adding field, and most industries are still at the rear of industrial chain in international division of labor. According to the smiling curve, added value in production is more embodied at the two ends of products - research/design and sales promotion while added value is the lowest for production and processing and assembly in the middle link[3]. See Fig. 1 below

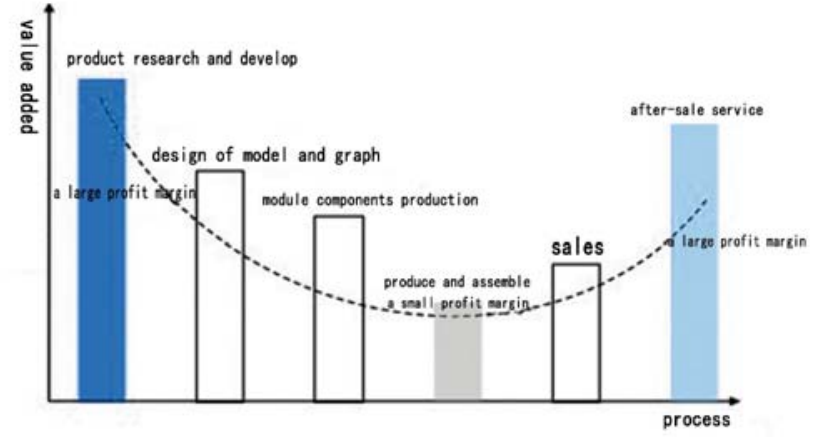

Fig. 1. Smiling Curve of Product Value Chain

As is shown in research, in order to thoroughly get rid of the OEM economic pattern that relies on foreign technologies and change China's middle-to-low position in the division of labor in the world's industrial chain, it is a must to foster hundreds of millions of technically capable workers. The postmodeling construction period in higher vocational education should not constrain its specialty building to being the base for fostering a production army under the existing division of labor in industrial chain; it should take a step further to make specialties the cradle for fostering and reserving tens of thousands of technical talents for the economic transformation as an important part of China's technological innovative team or even as a powerful weapon to enhance the industrial level of China and change the middle-to-low position of China in the international division of labor in industrial chains[4].

\section{A new challenge to specialty construction put out by the Plan for building the modern vocational educational system}

The National Medium and Long-term Educational Reform and Development Program (2010-2020) states: vocational education is to be developed vigorously so that, by 2020 , a modern vocational educational system is formed that is suitable to the demands put out by the pattern change of economic development and the structural adjustments of industries, embodies the idea of life-time education and the coordinated development of secondary and higher vocational educations in order to meet the economic and social needs for labors with high qualification and skilled talents.

The economic transformation requires that the goal of fostering specialty talents through higher vocational education change from fostering talents with ordinary operational skills to that with high level technical skills, that is to say, fostering grey-collar talents both capable of technical application and innovation and possessive of strong specialty skills[4]. New talent-fostering plans and curriculum systems should be worked out around three features of talents: compound, innovative and developing. A new round of constructions should be undertaken for specialty, curricula and project development activities based on the requirements of three- 
featured talents, which will further improve the talent fostering plans.

\section{How Can the Specialty Construction Be TRANSFORMED DURING THE ECONOMIC TRANSFORMATION PERIOD?}

It is the real proposition to be addressed at higher vocational institutes after the modeling period that the topic of content construction is revisited, new problems in building modern vocational educational systems is tackled positively and the big themes of Vocational Education Dream and China Dream are deliberated. During the economic transformation period, thanks to taking part in the world's division of labor and international competition, more and more enterprises in China have become global ones. The post-modeling specialty construction must change its direction from domestic enterprises to global ones in fostering talents with professional and technical skills to accomplish the transformations of talentfostering patterns, curriculum systems, course development, teaching teams, training bases, teaching methodologies and assessment systems[5].

\section{A. Merge into industries, and make prominent features of content construction}

The new round of adjustments of industrial structures will definitely provide new opportunities for regional economic developments as well as put out new demands for fostering talents with technical skills. In the post-modeling period, higher vocational institutes should use more rationality in dealing with the difficulties in student enrollment, employment and sourcing quality of students, and modify ideas about specialty construction, putting the content construction in the first place and taking the quality of talent fostering as a touchstone[7].

\section{B. Take specialty construction as the locomotive, and integrate resources of groups of majors}

The specialty construction during industrial structure transformation and upgrading has stepped into a key phase of deepening the content construction so as to comprehensively improve the quality of talent fostering. The Education Ministry's Advices on Comprehensively Improving the Quality of Higher Vocational Education and Teaching clearly states that higher vocational institutes should build groups of majors that are driven by key majors and supported by relevant majors in accordance with market needs and specific specialty setups, that spread services to regions, industries, enterprises and countryside concerned, and that enhance students' employability. From the viewpoints of policies, higher vocational institutes are expected to assume the important task to deepen the content construction and improve the quality of the building of groups of majors[8].

Due to the fact that all majors in a group share the same industrial background and professional jobs, pushing forward the construction of groups of majors make it possible to keep in time trace of the changes in industries and market needs, to know the common knowledge, skills and capabilities required by social groups or professions or working jobs, therefore, to be able to proactively adapt to the needs of the development of industries, regional economies and the society. In the postmodeling construction period, we are supposed to base ourselves on the conglomerating construction of industries, break barriers among specialties, integrate related resources of groups of majors, form conglomerating advantages of groups of majors, comprehensively raise the level of specialties in fostering talents with high qualification and technical skills in the industries and regions, manifest the features and brand advantages of specialties, and finally realize core competitiveness of specialty construction.

\section{Take course building as the handle, and transform the logical setoff point of teaching design}

According to the new changes and requirements after the adjustment of economic structures, we should introduce industrial and corporate technical standards into the development of project courses for specialties and redesign teaching processes. We should raise the logical setoff point in teaching designs from single need orientation to double need orientation. In the past we took job needs or professional needs as the logical setoff point of teaching design. Today, we should not only take as the logical setoff point job needs or professional needs, but also the needs of nurturing students' capabilities of technical digestion, absorption, innovation, reverse-engineering and creative activities[6].

In developing courses, we should not only strengthen skill training, but also reinforce professional qualification training; we should not only reflect the professional requirements of jobs that students are expected to master in the work flows of groups of majors, but also reflect the higher attribute of higher vocational education; meanwhile, we should also properly deal with the relations between work-based study and study-based work. This is an important handle of the specialty construction and course reformation during the post-modeling period.

\section{Take teaching team building as the carrier, and accomplish the transformation of teachers' role function}

The transformation and upgrading of economic development rely on technological progresses, the qualification of labors and innovative management, all in all, on talents with high qualification and technical skills while the key of talent fostering relies on double-certificate teachers. Facing the newly emerged industries and industrial structures, we must review and redefine the contents and criteria of double-certificate teachers, shift our emphasis on getting technical ranks or professional certificates to nurturing teachers with industrial disposition, especially with capabilities to solve difficult problems in industries and enterprises while enhancing the quality of double-certificates. The role of teachers is to be changed from teachers to project managers. We should build a team of double-certificate specialty teaching team within a group of majors with different knowledge structure, academic backgrounds, experiences from frontline production and interaction in full-time or part-time with research and business services. We should improve teaching with scientific research, establish and improve social services systems for teachers, develop contacts with various levels of governmental departments and industrial associations, guide teachers to 
provide technical services to enterprises in the industries, expand research channels and projects through ways such as marriage between enterprises and schools to raise the level of teachers' scientific research, solving the bottleneck of research in specialty construction.

\section{E. Expand the function of professional school-running, and create brands through international cooperation}

During the period of economic transformation, more and more Chinese enterprises have become globalized ones after taking part in the world's division of labor and international competition. The fostering of talents with professional technical skills also changes from serving domestic enterprises to serving globalized ones. The specialty construction during the post-modeling construction period is more expected to enhance quality inwardly and establish brands outwardly. It should stick to the openness of higher vocational education, set up ideas of education modernization and internationalization, center around the requirements of industrial development, serve the go out strategy of the national economy, take advantage of brand majors, make favorable policies on our own cooperate with multi-national groups and large-sized enterprises to jointly foster talents to meet the needs of overseas development of businesses. We should also build strategic partnership with our foreign counterparts with advanced vocational educational ideas. Thus, through overseas internship, joint fostering of targeted-area students, bidirectional co-education of exchange students, bi-directional communications of teachers, bi-directional part-time employment, and among other ways, we may promote the development of international cooperation and effectively widen the influence and publicity of China's higher vocational education.

To sum up, if we regard specialty construction as a finished dish, merging into industrial circles and building contents is the idea, groups of majors are equivalent to ingredients for preparing the dish, curriculum systems the recipe, talent fostering plans the cooking process, training bases the cooking facilities and logistics, teachers the cooking masters or managers, teaching methods the cook know-how, and social evaluation is the inspection of the effects of the finished specialty dish. How to prepare the dish of specialty construction will be a systematic project with a slight move in one part to be affecting the whole situation. During the economic transformation period, if the specialty construction becomes a powerful weapon in enhancing China's industrialization and changing the middle-to-low position of China in the International division of labor in industrial chains, we must accomplish as quickly as possible the innovation and transformation of the school-running and talent-fostering patterns, cooperation systems among industry, school and research, operation systems of school-enterprise cooperation and ways of social services.

\section{CONCLUSION}

During the period of economic transformation, majorconstruction of China's vocational education has stepped into a new era. Personnel cultivated by the originally industrial structure-centered majors can't meet needs of the changed industrial structure and economic development due to their high specialization and narrow social service. The majorconstruction in the post-demonstration period should grasp the chance of major structure transformation and upgrading, positively adapt to the structural adjustment of the global industrial structure and the appearance of new industries, and start a new adjustment and construction of the major structures. Thus, the major-construction concept, the position of personnel standards, the design of teaching process, the curriculum development, teacher training and evaluation system will be completed to make the majors become sources of innovation and highland of talents for schools, industries and society. In this way, China's economic transformation will be promoted, technology transformation upgraded, industrial level heightened, China's low status in international division of industry chain changed.

\section{REFERENCES}

[1] Tang Min, What Kind of Education does the third Industrial Revolution Need? [J]. Innovation Talent Education, 2013(05).

[2] Chen Guisheng. Educational principles, [M]. Shanghai: East China Normal University Press, 2000 (03).

[3] Wang Xiwen. "Internet + industry" farewell smile curve, [N] People's Posts and Telecommunications, 2015 (09-28).

[4] $\mathrm{Yu}$ Zhongwen.the times call for higher vocational education, [J].employment and security, 2013 (04).

[5] Cui Yan, Post-demonstration, How to Break through for Higher Vocational Education? [N]. Guangming Daily, 2013-12-07.

[6] Han Jihong, Li Shuming. An Analysis on the Construction and Development of Major Group Construction for Higher Vocational Schools in Post-demonstration Period, [J]. Educational Theory and Practice, 2013(27)

[7] Ke Wei, Tong Hongzhi. Thinking and Strategies on the Connotation Construction of Higher Vocational Schools in New Era, [J]. Journal of Hubei Correspondence University, 2013(06)

[8] Xu Shihao, A Research on the Link of Major-construction and Regional Economic Development in the Economic Transformation Era, [J]. Education Exploration, 2010(3) 